\title{
Endogenous Oxygen Uptake and Polysaccharide Accumulation in Bifidobacterium
}

\author{
Seiichi Shimamura, Fumiaki Abe, Norio Ishtbashi, \\ Hiroshi Mryakawa, Tomoko Yaeshima and Mamoru Tomita \\ Nutritional Science Laboratory, Morinaga Milk Industry Co., Ltd., \\ 1-83, Higashihara 5-chome, Zama-shi, Kanagawa 228, Japan
}

Received May 7, 1990

\begin{abstract}
To study the behavior of Bifidobacterium toward oxygen, oxygen uptake was investigated in detail. The cells of Bifidobacterial strains absorbed considerable amounts of oxygen. The exogenous oxygen uptake activity changed depending upon the period of incubation. Bifidobacterial cells also had high endogenous oxygen uptake, which was, in $B$. longum strains, as high as about $80 \%$ of the exogenous oxygen uptake activity. Bifidobacterial cells accumulated considerable amounts of polysaccharide, which was associated with cellular growth. By incubating the cultivated cells in a glucose-free medium, the endogenous oxygen uptake activity was decreased with a decrease of intracellular polysaccharide. Therefore it was postulated that the high endogenous oxygen uptake activity of Bifidobacterium was owing to the metabolism of intracellular polysaccharide. The enzymatic activity, which was involved in the mechanism of oxygen uptake, was also investigated.
\end{abstract}

Bifidobacterium is a dominant bacterium in the intestinal microflora of humans and animals, and is significant for the health of the host. Therefore, Bifidobacterium has been used in dairy products, ${ }^{1,2)}$ foods, and livestock feeds to supply numerous viable probiotic cells to the intestine. However, due to the strict anaerobicity of Bifidobacterium species, oxygen adversely affects the growth or viability of Bifidobacterium. In some cases, the environment in the food or feed products was lethal for Bifidobacterium. Studies on the mechanism of susceptibility of Bifidobacterium to oxygen are required so as to minimize the influence of oxygen in processing foods or feeds containing Bifidobacterium.

De Vreis ${ }^{3)}$ estimated the oxygen sensitivity of the extensive Bifidobacterial species by measuring the extent of growth inhibition at the surface of a semisolid culture medium in the test tube, or by comparing the growths when the incubation was shifted from anaerobic to aerobic conditions. Uesugi ${ }^{4,5)}$ also classified many genera of anaerobic bacteria, including Bifidobacterium, depending on their oxygen sensitivity, which was measured by comparing the growth in sealed fermentor vessels containing oxygen at various concentrations. De Vreis and Uesugi studied the correlation between the oxygen sensitivity and the enzyme activities relating to oxygen metabolism of Bifidobacterium. However, no difinite relationship has been obtained yet.

In this study, we measured the oxygen uptake activity of Bifidobacterium to study the behavior of Bifidobacterium toward oxygen, and observed a notable correlation between the endogenous oxygen uptake activity and the intracellular polysaccharide accumulation that was associated with the growth of the Bifidobacterial cell. The enzymatic activity, which was involved in the mechanism of oxygen uptake, was also investigated.

\section{Materials and Methods}

1. Bacterial strains and culture condition. Six strains of Bifidobacterium and two strains of Lactobacillus were used in this study.

Bifidobacterium bifidum (ATCC 15696), B. infantis (ATCC 15697), B. breve (ATCC 15700), B. adolescentis (ATCC 15703), and B. longum (ATCC 15707) were purchased from the American Type Culture Collection, 
and B. longum (BB536) was isolated from the stool of a healthyl infant by the authors.

Lactobacillus helveticus (ATCC8018) and Lactobacillus casei (IFO3425), which were the authentic standard strains of Lactobacillus, were purchased from the ATCC and IFO Culture Collection, respectively. The bacterial strains were cultured at $37^{\circ} \mathrm{C}$ for $14-16 \mathrm{hr}$ and stored as $5^{\circ} \mathrm{C}$ in the culture medium containing lactose $(1 \%)$, yeast extract $(1 \%)$, meat extract $(0.5 \%)$, Bacto-Casitone $(1 \%), \mathrm{KH}_{2} \mathrm{PO}_{4}$ $(0.1 \%), \mathrm{K}_{2} \mathrm{HPO}_{4}(0.1 \%), \mathrm{CH}_{3} \mathrm{COONa}(0.7 \%)$, and cystine $(0.04 \%)$. For the preparation of the bacterial cells for the experiment, each strain was cultured in a flask for 8 or $15 \mathrm{hr}$.

2. Preparation of cell suspensions and cell-free extracts. After cooling the bacterial culture, cells were harvested by centrifugation at $6,000 \times g$ at $5^{\circ} \mathrm{C}$ for $10 \mathrm{~min}$, washed twice with an equal volume of saline, and finally suspended in $0.05 \mathrm{M}$ phosphate buffer ( $\mathrm{pH} \mathrm{6.8)}$ and tested. The cell-free extracts were prepared by disrupting cells by sonic oscillation and subsequently discarding the cell debris by centrifugation at $20,000 \times g$ for $30 \mathrm{~min}$.

3. Measurement of protein and polysaccharide in the cell-free extract. Protein in the cell-free extract was measured by the pyrogallol red method. ${ }^{6}$ Polysaccharide in the cell-free extract was estimated by the analysis of glucose, which was liberated by acid or enzymatic hydrolysis, by the glucose oxidase method (Glucose Test $\mathrm{B}$, Wako Pure Chemical Industries Inc.). Acid hydrolysis of the cell-free extract was done with $2 \mathrm{~N} \mathrm{H}_{2} \mathrm{SO}_{4}$ at $100^{\circ} \mathrm{C}$ for $2 \mathrm{hr}$, and enzymatic hydrolysis was done with amyloghucosidase (Sigma, EC 3.2.1.3, 37 units/mg) at a concentration of $2 \mathrm{mg} / \mathrm{ml}$ at $37^{\circ} \mathrm{C}$ for $2 \mathrm{hr}$ in $0.04 \mathrm{M}$ acetate buffer ( $\mathrm{pH} 4.5$ ).

4. Oxygen uptake in the cell and measurement of oxidase activities. Oxygen uptake in the cell was measured by the Warburg manometer. To $0.5 \mathrm{ml}$ of phosphate buffer ( $\mathrm{pH}$ 7.0) in the main compartment of the Warburg cuvette, $0.5 \mathrm{ml}$ of bacterial cell suspension was added. In the sub and side compartments of the cuvette, $0.2 \mathrm{ml}$ of $5 \mathrm{M} \mathrm{KOH}$ and $0.5 \mathrm{ml}$ of substrate solution were placed, respectively. After equilibrating the temperature at $37^{\circ} \mathrm{C}$, the substrate solution was added and the exogenous oxygen absorption was measured manometrically. To estimate the endogenous oxygen uptake, water was used instead of substrate solution.

Oxidase activity in the cell-free extract was estimated by a modification of the method used for measurement of oxygen uptake of the cell. The cell-free extract was used instead of the cell suspension and substrates such as sodium pyruvate $(10 \mathrm{~mm})$, DL-malate $(10 \mathrm{mM})$, DL-alanine $(10 \mathrm{mM})$ or $\mathrm{NADH}(5 \mathrm{~mm})$ was used. For the test of oxidase inhibition, the addition of sodium cyanide ( $1 \mathrm{~mm}), \mathrm{CuSO}_{4}$ ( $1 \mathrm{~mm}$ ), or $p$-chloromercuribenzoate (PCMB, $0.1 \mathrm{mM}$ ) to the reaction mixture was made at the onset of reaction.

\section{Results and Discussion}

\section{Activity of oxygen uptake in the bacterial cells}

The oxygen uptake activities of the Bifidobacterial cells are shown in Table I. All Bifidobacterial strains took up considerable oxygen when they used glucose as a carbon source, although the activities seemed rather lower than the values reported by Uesugi, ${ }^{5}$ ) but were comparable to those of two Lactobacillus species in this study and Streptococcus thermophilus reported by Teraguchi et al. ${ }^{7)}$ The difference in exogenous oxygen uptake between the cells with 8 and $15 \mathrm{hr}$ of incubation seemed to have varied depending upon the cultivation time of the strain. However, considerable level of activity was observed in both 8 and 15 hr' cells of every strain.

The oxygen uptake of the cells of $B$. infantis, $B$. breve, and two strains of $B$. longum after $15 \mathrm{hr}$ ' incubation in the presence of glucose, lactose, or fructose as substrate, are presented in Table II. While all strains tested here had slightly lower activity with fructose than with glucose and lactose as substrate, the exogenous oxygen uptake seemed not to vary irrespective of the monosaccharide species. This indicates that oxygen is taken up when a metabolizable sugar is present. Some metabolites derived from monosaccharide may act as direct substrates for terminal oxygen reduction.

Endogenous oxygen uptake of Bifidobacterium during the incubation in the absence of the metabolizable energy sources was studied (Tables I, II). The endogenous oxygen uptake was markedly higher especially in cells cultured for $15 \mathrm{hr}$. About $74-83 \%$ of the exogenous oxygen uptake activity was retained when the cells of two B. longum strains were incubated in the absence of the energy sources (Tables I, II). This endogenous oxygen uptake of Bifidobacterium is obviously higher than those of two Lactobacillus species, which was less than $1 \%$ of the exogenous oxygen uptake activity. The experimental results, showing that endogenous oxygen uptake by the cells after incubating for $15 \mathrm{hr}$ was higher than those after 
Table I. OXYGEN UPTAKE ACTIVITIES OF Bifidobacterium AND Lactobacillus STRAINS

\begin{tabular}{|c|c|c|c|c|c|}
\hline \multirow{2}{*}{ Strains } & \multirow{2}{*}{$\begin{array}{c}\text { Cultivation } \\
\text { time } \\
\text { (hr) }\end{array}$} & \multirow{2}{*}{$\begin{array}{c}\text { Culture } \\
(\mathrm{pH})\end{array}$} & \multicolumn{2}{|c|}{$\begin{array}{l}\text { Oxygen uptake* } \\
(\mu \mathrm{l} / \mathrm{mg} \text { cell }, \mathrm{hr})\end{array}$} & \multirow{2}{*}{$\frac{\text { Ratio }(\%)}{\text { Endo/Exo }}$} \\
\hline & & & Exogenous & Endogenous & \\
\hline Bifidobacterium & 8 & 6.20 & 4.2 & 0.0 & 0 \\
\hline bifidum (ATCC15696) & 15 & 5.12 & 7.7 & 3.4 & 44.2 \\
\hline Bifidobacterium & 8 & 5.25 & 3.0 & 0.7 & 23.3 \\
\hline infantis (ATCC15697) & 15 & 4.33 & 4.9 & 1.9 & 38.8 \\
\hline Bifidobacterium & 8 & 4.89 & 4.6 & 1.6 & 34.8 \\
\hline breve (ATCC15700) & 15 & 4.46 & 5.4 & 3.4 & 63.0 \\
\hline Bifidobacterium & 8 & 4.52 & 3.6 & 1.1 & 30.6 \\
\hline adolescentis (ATCC15703) & 15 & 4.47 & 3.1 & 1.6 & 51.6 \\
\hline Bifidobacterium & 8 & 4.95 & 6.9 & 1.7 & 24.6 \\
\hline longum (ATCC15707) & 15 & 4.50 & 4.1 & 3.4 & 82.9 \\
\hline Bifidobacterium & 8 & 5.00 & 4.4 & 0.7 & .15 .9 \\
\hline longum (BB536) & 15 & 4.65 & 3.8 & 2.8 & 73.7 \\
\hline \multicolumn{6}{|l|}{ Lactobacillus } \\
\hline casei (IFO3425) & 15 & 4.25 & 6.5 & 0.07 & 1.1 \\
\hline \multicolumn{6}{|l|}{ Lactobacillus } \\
\hline helveticus (ATCC8018) & 15 & 4.11 & 7.3 & 0.05 & 0.7 \\
\hline
\end{tabular}

* Warburg manometer: Main cell, $0.2 \mathrm{~m}$ phosphate buffer ( $\mathrm{pH} 7.0$ ) $0.5 \mathrm{ml}$; cell suspension $0.5 \mathrm{ml}$. Sub cell, $5 \mathrm{M}$ $\mathrm{KOH}, 0.2 \mathrm{ml}$. Side cell, glucose soln. $0.5 \mathrm{ml}\left(0.5 \mathrm{M}\right.$ final conc.). Reaction, $37^{\circ} \mathrm{C}$.

Table II. OXYGEn UPTAKe Activities of Bifidobacterium AND Lactobacillus Strains By Different SUgars

\begin{tabular}{|c|c|c|c|c|}
\hline \multirow[t]{3}{*}{ Strains } & \multicolumn{4}{|c|}{ Oxygen uptake* $(\mu \mathrm{l} / \mathrm{mg}$ cell, hr $)$} \\
\hline & \multicolumn{3}{|c|}{ Exogenous } & \multirow{2}{*}{ Endogenous } \\
\hline & Glucose & Lactose & Fructose & \\
\hline B. bifidum (ATCC15696) & 7.9 & 7.5 & 6.2 & 2.8 \\
\hline B. breve (ATCC15700) & 4.3 & 4.5 & 4.2 & 3.1 \\
\hline B. longum (A TCC15707) & 4.1 & 4.0 & 3.8 & 3.0 \\
\hline L. casei (IFO3425) & 6.2 & 6.8 & 5.4 & 0.09 \\
\hline L. helveticus (ATCC8018) & 7.7 & 7.9 & 7.1 & 0.03 \\
\hline
\end{tabular}

* Warburg manometer: Main cell, $0.2 \mathrm{M}$ phosphate buffer (pH 7.0) $0.5 \mathrm{ml}$; cell suspension $0.5 \mathrm{ml}$. Sub cell, $5 \mathrm{M}$ $\mathrm{KOH}, 0.2 \mathrm{ml}$. Side cell, $0.5 \mathrm{~m}$ sugar solution, $0.5 \mathrm{ml}$. Reaction, $37^{\circ} \mathrm{C}$.

Table III. Changes of Oxygen Uptake Activities upon Washing the Cells of B. longum (ATCC15707)

\begin{tabular}{ccc}
\hline $\begin{array}{c}\text { Frequency of } \\
\text { washing } \\
\text { (times) }\end{array}$ & Oxygen uptake* $(\mu \mathrm{l} / \mathrm{mg}$ cell, hr $)$ \\
\cline { 2 - 3 } & Exogenous & Endogenous \\
\hline 2 & 8.3 & 5.8 \\
6 & 7.6 & 6.0 \\
6 & 9.9 & 6.9 \\
\hline
\end{tabular}

* Warburg manometer (same conditions as in Table I). incubating for $8 \mathrm{hr}$, and that the ratio of endogenous to exogenous oxygen uptake activity is higher in $15 \mathrm{hr}$ ' cultivated cells $(38.8-82.9 \%)$ than those of $8 \mathrm{hr}(0-34.8 \%)$, was also noted (Table I).

It has observed that the endogenous oxygen uptake by some bacteria or cultured animal cells often decreased as cell washing was repeated ${ }^{8)}$ However, as shown in Table III, the high endogenous oxygen uptake activity of Bifidobacterium was retained even after they 
were washed six times with saline. Therefore, it is conceivable that this endogenous oxygen uptake is not caused by the substrate which might have been adsorbed to the cell surface of Bifidobacterium, and that some intracellular substrates may supply the energy for this endogenous oxygen uptake. The higher endogenous activity, in the cell of $15 \mathrm{hr}$ ' incubation, suggests the accumulation of an intracellular substrate that is associated with cellular growth.

\section{Intracellular polysaccharide in Bifidobac- terium}

Glycogen is an intracelluar energy source that is accumulated in microorganisms such as Escherichia coli, ${ }^{9)}$ yeast, ${ }^{10}$ ) and anaerobic bacteria. ${ }^{1-13)}$ Polyhydroxybutyrate (PHB) is also a bioplastic material accumulated in the cells of Bacillus species. ${ }^{14)}$

By analyzing the intracellular polysaccharide and PHB of Bifidobacterium, the accumulation of polysaccharide was verified. The polysaccharide accumulated in the Bifidobacterial cells was measured by analyzing glucose, which was liberated by acid or enzymatic hydrolysis (Table IV). The values obtained by enzymatic hydrolysis were lower than those by acid hydrolysis. This inconsistency in the results in polysaccharide analysis between the acid and enzymatic hydrolysis is probably due to the limited hydrolysis by amyloglucosidase. From the observation about the difference in polysaccharide values by acid and enzymatic hydrolysis, a diversified structure or condition of polysaccharide in the cells of Bifidobacterial strains is conceivable. Further investigation is required for this issue, but the significance of the polysaccharide was discussed based on the values by acid hydrolysis in the following.

Polysaccharide accumulated as the bacterial growth proceeded. The polysaccharide was then presumed to supply energy for the endogenous oxygen uptake. When the concentration of polysaccharide was compared in the cell after $15 \mathrm{hr}$ of incubation, higher accumulation was observed in Bifidobacterial strains than in Lactobacillus. The polysaccharide contents in the dried cells of Bifidobacterium were from 6.4 to $15.1 \%$ (Table IV). Therefore these results are also compatible with the hypothesis that the accumulated polysaccharide supplies the energy for the endogenous oxygen uptake in Bifidobacterium.

Table IV. Intracellular POlysaccharide of Bifidobacterium and Lactobacillus STRains

\begin{tabular}{|c|c|c|c|}
\hline \multirow{2}{*}{ Strains } & \multirow{2}{*}{$\begin{array}{c}\text { Cultivation } \\
\text { time } \\
\text { (hr) }\end{array}$} & \multicolumn{2}{|c|}{ Polysaccharide } \\
\hline & & Acid hydrolysis*** & Enzyme hydrolysis**** \\
\hline \multirow[t]{2}{*}{ B. bifidum (ATCC15696) } & 8 & $0.12^{*}\left(0.68^{* *}\right)$ & $<0.01^{*}\left(<0.05^{* *}\right)$ \\
\hline & 15 & $0.22(6.40)$ & $0.16(4.65)$ \\
\hline \multirow[t]{2}{*}{ B. infantis (ATCC15697) } & 8 & 0.34 & $0.25(5.32)$ \\
\hline & 15 & 0.68 & $0.54(7.11)$ \\
\hline \multirow[t]{2}{*}{ B. breve (ATCC15700) } & 8 & $0.48 \quad(8.64)$ & $0.36(6.48)$ \\
\hline & 15 & $0.94(15.1)$ & $0.63(10.1)$ \\
\hline \multirow[t]{2}{*}{ B. adolescentis (ATCC15703) } & 8 & $0.41(8.12)$ & $0.01 \quad(0.20)$ \\
\hline & 15 & $0.45(9.62)$ & $0.10(2.14)$ \\
\hline \multirow[t]{2}{*}{ B. longum (ATCC15707) } & 8 & $0.38(7.36)$ & $0.31(6.00)$ \\
\hline & 15 & $1.26 \cdot(13.3)$ & $0.99(10.4)$ \\
\hline \multirow[t]{2}{*}{ B. longum (BB536) } & 8 & $0.15(2.60)$ & $0.14(2.42)$ \\
\hline & 15 & $1.03(12.9)$ & $1.00(12.5)$ \\
\hline L. casei (IFO3425) & 15 & $0.02(<0.05)$ & $<0.01 \quad(<0.05)$ \\
\hline L. helveticus (ATCC8018) & 15 & $0.02(<0.05)$ & $<0.01 \quad(<0.05)$ \\
\hline
\end{tabular}

* $\mathrm{mg} / \mathrm{mg}$ protein in cell free extract.

** Percent content in dry cell.

*** $2 \mathrm{~N} \mathrm{H}_{2} \mathrm{SO}_{4}, 100^{\circ} \mathrm{C}, 2 \mathrm{hr}$.

**** Amyloglucosidase $2 \mathrm{mg} / \mathrm{ml}, 37^{\circ} \mathrm{C}, 2 \mathrm{hr}, \mathrm{pH} 4.5$. 
Table V. Changes of Oxygen Uptake Activities and Intracellular Polysaccharide of Bifidobacterium Strains upon InCubating in Carbon-FreE MEdium

\begin{tabular}{|c|c|c|c|c|}
\hline \multirow{2}{*}{ Strains } & \multirow{2}{*}{ Incubation* } & \multicolumn{2}{|c|}{ Oxygen uptake** $(\mu l / \mathrm{mg}$, cell, hr $)$} & \multirow{2}{*}{$\begin{array}{l}\text { Polysaccharide** } \\
\text { (mg/mg protein) }\end{array}$} \\
\hline & & Exogenous & Endogenous & \\
\hline B. bifidum & Before & 6.9 & 3.7 & 0.33 \\
\hline (ATCC15696) & After $(6 \mathrm{hr})$ & 5.9 & 0.8 & 0.05 \\
\hline B. infantis & Before & 4.1 & 3.4 & 0.96 \\
\hline (ATCC15697) & After ( $8 \mathrm{hr})$ & 3.7 & 0.4 & 0.04 \\
\hline B. breve & Before & 5.3 & 3.1 & 0.79 \\
\hline (ATCC15700) & After (4hr) & 4.9 & 0.2 & 0.26 \\
\hline B. adolescentis & Before & 1.6 & 0.9 & 0.67 \\
\hline (ATCC15703) & After ( $8 \mathrm{hr})$ & 1.2 & 0.0 & 0.26 \\
\hline B. longum & Before & 4.5 & 4.2 & 0.88 \\
\hline (ATCC15707) & After $(8 \mathrm{hr})$ & 5.9 & 0.5 & 0.08 \\
\hline B. longum & Before & 3.9 & 3.7 & 1.72 \\
\hline (BB536) & After $(8 \mathrm{hr})$ & 5.8 & 0.0 & 0.03 \\
\hline
\end{tabular}

* Washed cells were resuspended in the carbon-free medium and incubated at $37^{\circ} \mathrm{C}$.

** The oxygen uptake activity and polysaccharide were measured in both cells before and after incubation.

Table VI. Oxygen Uptake by Cell-free Extracts of Bifidobacterium Strains

\begin{tabular}{|c|c|c|c|}
\hline \multirow[b]{2}{*}{ Substrate } & \multicolumn{3}{|c|}{ Oxygen uptake* ( $\mu 1 / \mathrm{mg}$ protein, hr) } \\
\hline & $\begin{array}{c}\text { B. bifidum } \\
\text { (ATCC15696) }\end{array}$ & $\begin{array}{c}\text { B. breve } \\
\text { (ATCC15700) }\end{array}$ & $\begin{array}{c}\text { B. longum } \\
(\text { ATCC15707) }\end{array}$ \\
\hline None & 0.0 & 0.0 & 0.0 \\
\hline Na-Pyruvate $(10 \mathrm{~mm})$ & 0.0 & 0.0 & 0.0 \\
\hline DL-Malate $(10 \mathrm{~mm})$ & 0.0 & 0.0 & 0.0 \\
\hline DL-Alanine $(10 \mathrm{~mm})$ & 0.0 & 0.0 & 0.0 \\
\hline NADH $(5 \mathrm{~mm})$ & 37.1 & 10.4 & 38.4 \\
\hline $\mathrm{NADH}(5 \mathrm{mM})+\mathrm{CN}^{-}(1 \mathrm{~mm})$ & 35.6 & 11.6 & 36.6 \\
\hline $\mathrm{NADH}(5 \mathrm{mM})+\mathrm{Cu}^{++}(1 \mathrm{mM})$ & 0.2 & 0.3 & $\mathrm{NT}^{* *}$ \\
\hline $\mathrm{NADH}(5 \mathrm{mM})+\mathrm{PCMB}(0.1 \mathrm{~mm})$ & 2.7 & 0.9 & NT \\
\hline
\end{tabular}

* Warburg manometer: Main cell, $0.2 \mathrm{M}$ phosphate buffer ( $\mathrm{pH} 7.0$ ) $0.5 \mathrm{ml}$; cell-free extract $0.5 \mathrm{ml}$. Sub cell, $5 \mathrm{M} \mathrm{KOH}, 0.2 \mathrm{ml}$. Side cell, $0.5 \mathrm{ml}$ of substrate or substrate and inhibitor soln. with a final conc. as shown in the table. Reaction, $37^{\circ} \mathrm{C}$.

** Not tested.

Two Lactobacillus of which the intracellular polysaccharide was very low had only limited endogenous oxygen uptake (Tables I, IV).

To clarify the significance of intracellular polysaccharide in the endogenous oxygen uptake, the correlation of consumption of polysaccharide with the oxygen uptake activity was analyzed. The washed cells of each strain were resuspended in glucose-free culture medium of the same composition and then incubated at $37^{\circ} \mathrm{C}$ for 4 to $8 \mathrm{hr}$. As shown in Table $\mathrm{V}$, in all Bifidobacterial strains, the endogenous oxygen uptake activity decreased with the decrease of their intracellular polysaccharide, while their exogenous oxygen uptake remained around the same level. This result indicates that Bifidobacterial cells are reduced in their endogenous oxygen uptake activities by incubating in the carbon-free medium, due to the lack of an intracellular energy source, while the cells retained oxygen uptake activities when the substrate was present. Therefore, it was concluded that the high activity of endogenous oxygen uptake of 
Bifidobacterium was owing to the metabolism of intracellular polysaccharide that was accumulated.

\section{Enzyme system for oxygen uptake of} Bifidobacterium

For terminal oxygen oxidoreductase of bacteria, NADH oxidase, ${ }^{15)}$ pyruvate oxidase, ${ }^{16)}$ malate oxidase, ${ }^{17)}$ amino acid oxidase, ${ }^{18\}}$ and glucose oxidase ${ }^{19)}$ are reported. NADH oxidase also operates in Bifidobacterium. $^{20)}$ The oxygen uptake by cell-free extracts of $B$. bifidum, $B$. breve, and B. longum (ATCC15707) was studies when NADH, Na-pyruvate, DL-malate, or DL-alanine was added as substrate, and is presented in Table VI. Oxygen uptake was observed only when NADH was used as the substrate. The oxygen uptake activity with $\mathrm{NADH}$ was not inhibited by $\mathrm{CN}^{-}(1 \mathrm{mM})$ but was completely inhibited by $\mathrm{Cu}^{2+}(1 \mathrm{mM})$ and $p$-chloromercuribenzoate $(0.1 \mathrm{~mm})$, which are inhibiting agents for NADH oxidase. ${ }^{21,22)}$ This indicated that the NADH oxidase operated in the mechanism of oxygen uptake as the terminal oxygen oxidoreductase in Bifidobacterium.

E. coli and many other microorganisms accumulate glycogen in their cells. From our observation that the cells of every thested Bifidobacterial strain accumulated considerable amounts of polysaccharide, polysaccharide accumulation also seemed to be a common feature of the genus Bifidobacterium. The reason why Bifidobacterium accumulates polysaccharide is still obscure. If this polysaccharide is the secondary energy source for the cell and can be metabolized when the primary substrate is exhausted, the amount of polysaccharide may reflect the biological activity of the cell.

In Lactobacillus and Streptococcus, ${ }^{15)}$ the phenomenon of oxygen uptake, which is caused by NADH oxidase, is considered to reduce the toxic effect of oxygen. The biological significance of the observed oxygen uptake in anaerobic Bifidobacterium is not clarified yet, but it probably plays the same role, to reduce oxygen toxicity. The high endogenous oxygen uptake activity in Bifidobacterium, which is caused by the intracellular polysaccharide, is considered to be effective to diminish the environmental oxygen when a primary substrate is absent.

For the elucidation of the biological role of oxygen uptake and polysaccharide accumulation in Bifidobacterium, comprehensive studies concerning the oxygen sensitivity and the enzyme activities relating to the oxygen metabolism are essential.

\section{References}

1) J. L. Rasic and J. A. Kurmann, "Bifidobacteria and Their Role", Birkhauser Verlag, 1983.

2) J. L. Rasic, North European Dairy J., 49, 80 (1983).

3) W. de Vreis and A. H. Stouthamer, Arch. Mikrobiol., 65, 275 (1969).

4) I. Uesugi and M. Yajima, Zeit. Allgem. Mikrobiol., 18, 287 (1978).

5) I. Uesugi and M. Yajima, Zeit. Allgem. Mikrobiol., 18, 593 (1978).

6) Y. Fujita, M. Itsuo and S. Kitano, Jpn. Soc. Anal. Chem., 32, E379 (1983).

7) S. Teraguchi, J. Ono, I. Kiyosawa and S. Okonogi, J. Dairy Sci., 70, 514 (1987).

8) T. Sekine, T. Sasagawa, S. Morita and H. Takahashi, "Warburg Manometer," Nankodo, Tokyo, 1961.

9) S. Govons, R. Vinopal, J. Ingraham and J. Preiss, J. Bacteriol., 97, 970 (1969).

10) H. Nakajima, I. Oshima, M. Yashiro, K. Yoda, M. Yamasaki and G. Tamura, Agric. Biol. Chem., 51, 2679 (1987).

11) Y. Kamio, Y. Terawaki, T. Nakajima and K. Matsuda, Agric. Biol. Chem., 45, 209 (1981).

12) R. E. Hungate, J. Bacteriol., 86, 848 (1963).

13) R. J. Wallace, Appl. Environ. Microbiol., 39, 630 (1980).

14) E. A. Dawes and D. W. Ribbons, Bact. Rev., 28, 126 (1964).

15) S. Condon, FEMS Micriobiol. Rev., 46, 269 (1987).

16) F. R. Williams and L. P. Hager, Arch. Biochem. Biophys., 116, 168 (1966).

17) D. V. Corn, J. Biol. Chem., 233, 299 (1958).

18) M. Dixon and K. Kleppe, Biochim. Biophys. Acta, 96, 368 (1965).

19) B. E. P. Swoboda and V. Massey, J. Biol. Chem., 240, 2209 (1965)

20) T. Kaneko, T. Murao, T. Takahashi, and F. Tsuchiya, Nippon Nōgeikagaku Kaishi, 59, 589 (1985).

21) C. F. Strittmatter, J. Biol. Chem., 234, 2789 (1959).

22) C. F. Strittmatter, J. Biol. Chem., 234, 2794 (1959). 